\title{
DOCUMENTING THE INTANGIBLE AND THE USE OF “COLLECTIVE MEMORY” AS A TOOL FOR RISK MITIGATION
}

\author{
${\text { Z. } \text { Ekim }^{\text {a }} \text {, E. E. Güney }}^{\mathrm{b}}$, M. Vatan ${ }^{\mathrm{c}}$ \\ ${ }^{\text {a }}$ Carleton University, Azrieli School of Architecture \& Urbanism, Ottawa, Ontario, Canada - ekimzeynep@gmail.com \\ ${ }^{\mathrm{b}}$ Bahcesehir Unv. Faculty of Architecture and Design, Besiktas, Istanbul, Turkey - efsuney@gmail.com \\ ${ }^{c}$ Bahcesehir Unv. Faculty of Architecture and Design, Besiktas, Istanbul, Turkey - meltemvatan@gmail.com
}

KEY WORDS: Cultural heritage, Documentation, Intangible Values, Collective Memory, Identity, Risk Mitigation

\begin{abstract}
:
Increasing immigration activities due to globalized economies, political conflicts, wars and disasters of the recent years not only had a serious impact on the tangible heritage fabric, but also on the intangible values of heritage sites. With the challenges of managing drastic changes the field of heritage is faced with in mind, this paper proposes a documentation strategy that utilizes "collective memory" as a tool for risk mitigation of culturally diverse sites. Intangible and tangible values of two cases studies, from Turkey and Canada, are studied in a comparative way to create a methodology for the use of collected data on "collective memory and identity" in risk mitigation and managing change as a living value of the site.
\end{abstract}

\section{INTRODUCTION}

"Collective memory" includes different perspectives and approaches that could be defined as its plurality and complexity in terms of commemorative practises, politics, and use of urban space and structuring of identity. It includes both tangible and intangible values. "Collective memory" is a tool of social and political culture to remember or to forget the past and to structure the future. Based on its complexity it is part of interdisciplinary field of "memory studies" (Reuben et al, 2008).

Within the scope of this paper intangible values of "collective memory" and the tangible components of structuring the intangible values are dealt with to specify its characteristics as tools for heritage risk mitigation. Contribution is done by analysing two case studies as Taksim Square, Istanbul and Kensington Market in Toronto, Ontario.

\subsection{Aim}

This paper explores the significance of "collective memory" in the context of heritage protection and risk mitigation of cultural heritage. In particular, the effects of forced migration, political conflicts, wars and disasters etc. on heritage and collective memory are investigated in order to emphasize the direct link between community, identity and memory. Cultural identity is formed by "collective memory" through accumulated traditions and rituals that are linked to the places which communities associate themselves with. Therefore, the longevity of communal identities could be ensured by the protection of "collective memory". However, the two-folded nature of heritage and collective memory with both tangible and intangible values creates challenges regarding their conservation, particularly with regards to the documentation of the intangible and the use of this collected data for the "management of change" as a tool of risk mitigation.

Meaning and definition of "collective memory" need to be considered in its all forms - tangible and intangible - and inherited heritage values of a place should be communicated to the next generations. Within this context, cultural heritage is examined as a living expression where "collective memory" takes one part. So, change is indispensable in any living expression. However, when the issue is protection of cultural heritage, the meaning and acceptance of change is a challenge faced. At this point authenticity could be stated as the basis of protection.

This paper aims to develop a digital documentation methodology for heritage sites in order to define "collective memory" characteristics as a tool to be consigned to posterity. Two cases - Taksim Square, Istanbul and Kensington Market in Toronto, Ontario are explored in a comparative way in an aim to reveal originalities and common characteristics in terms of heritage risk mitigation based on "collective memory".

\subsection{Methodology}

The methodology of this study is based on qualitative research approach and it is supported by data collection through an extensive literature review, observations and documentation of the site. Collected data is digitized in terms of documentation of collective memory characteristics within heritage risk mitigation.

The idea is to reach a holistic understanding via extensively exploring the selected case studies to explain characteristics of "collective memory" and its use as a tool for heritage risk mitigation. Contributed overview provides an in-depth

* Corresponding author 
understanding of the selected case studies within their own unique conditions rather than make a generalization for similar cases. However, the attempt is to prepare a digital platform for data collection in order to be used as risk mitigation tool based on "collective memory".

The methodology of this study is based on theoretical and empirical approach in order to define characteristics of "collective memory". Theoretical part includes an extensive literature review to state definitions, narratives of the meaning of "collective memory" within the scope of memory studies and its values (Reuben et al, 2008; Foote and Azaryahu, 2007; Hoelscher and Alderman, 2004; Till, 2006). Additionally, risk mitigation strategies and risk management researches are explored in order to define the usable tools for the case studies of this paper (Romao et al., 2016; UNDP, 2010). Empirical part includes case studies and their data collection and defining of characteristics of "collective memory" as risk mitigation tools. Figure 1 shows the steps of the methodology of this study.

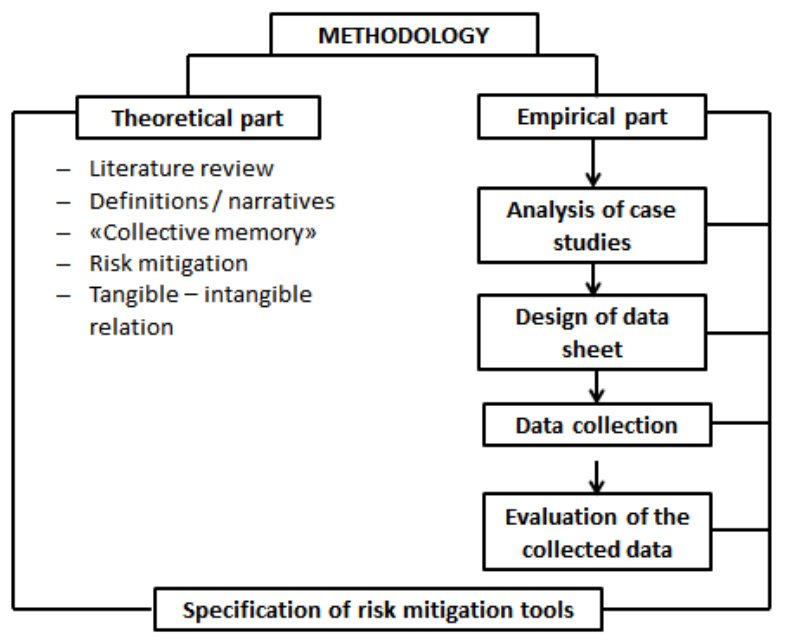

Figure 1: Steps of the methodology

Although the focus of this study is to document the intangible values of both case studies the tangible components of the sites take great importance. Particularly, photographs are the main part of the documentation intangible values and to trace the changes through the time. This could be stated as the power of reminiscence of the heritage.

\subsection{Originality / Contribution to the Field of Heritage Protection}

The term "collective memory" includes a comprehensive meaning with all of its tangible and intangible components. It could be linked to a specific place, location, building through photographs or a diary written in that place or it could be connected to the place through sensory stimuli that activates memories of past events. Its phenomena are based on belonging to a community or a group of people who come together with the same purpose in order to act and be part of it.

Using "collective memory" as a tool of cultural heritage protection presents challenges when globalization is considered. Additionally, increasing number of losses and negative effects on the heritage and collective memory due to forced migration, conflicts, war situation, devastating disasters and the like are challenges faced as well. On one hand, living in large cities, having cosmopolitan and multi-layered population structures, ideology and religion differences have negative impacts on "collective memory". On the other hand these characteristics bring diversity and create new communities for creating future "collective memory".

With all these growing challenges in mind, this paper aims to contribute to the field of heritage by creating a strategy for the recording of intangible qualities and their use as a tool for heritage risk mitigation. The two comparative case studies will analyse differing meanings of 'collective memory' and discuss its importance for a more holistic protection heritage.

\section{CHARACTERISTICS OF "COLLECTIVE MEMORY” AS HERITAGE RISK MITIGATION TOOLS}

Within the scope of this study characteristics of "collective memory" are based on places of memory in order to define tangible - intangible relation of its structuring. Mostly, "collective memory" is structured by places of memory by means of social events in particular times such as political changes, conflicts, disasters and the like. These events could be interpreted and analysed from two perspectives- theoretical and empirical- in order to define characteristics of "collective memory". Both approaches support the values of the other.

From perspective of Dylan Trigg "without the memory of places, memory itself would no longer have a role to play in our conscious lives." (Trigg, 2013). Parallel to this expression, it is possible to state that a place procures its meaning by link to the values of its land and community which belongs to it. These tangible and intangible values shape communities and their identities as "collective memory".

Meanwhile, Julieta M. Vasconcelos Leite explains "collective memory" as "... a process that establishes a relationship and identity between territories/physical spaces and individuals. Place is put forward as the space that participates in the collective memory, the fruit of the simultaneous process of the social construction of space and the construction of social space...” (Leite, 2009).

Understanding the interaction of values of "collective memory" and risk assessment requirements is the basis of defining risk mitigation tools. Within the scope of this study, main characteristics of "collective memory" are divided into two as tangible and intangible values. Data collection is made through designed data sheets for having objective and comparative evaluation (Figure 2). 


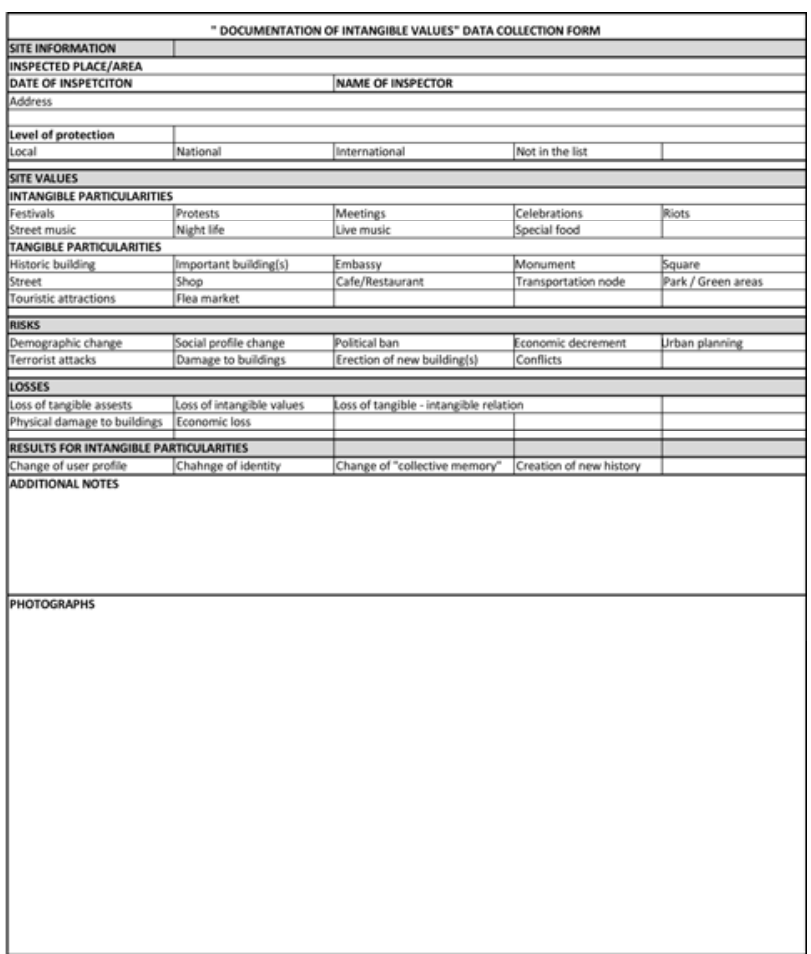

Figure 2: Blank Data Collection Form

\section{CASE STUDIES: TAKSIM SQUARE, ISTANBUL AND KENSINGTON MARKET IN TORONTO, ONTARIO}

\subsection{Taksim Square, Istanbul}

Taksim Square is strategically located on the north-west side of Istanbul in Beyoğlu district (Figure 3, 4), in close proximity to both the Bosphorus and Istanbul's Historic Peninsula. It also could be stated as one of the cores and city centres of Istanbul metropolitan city.

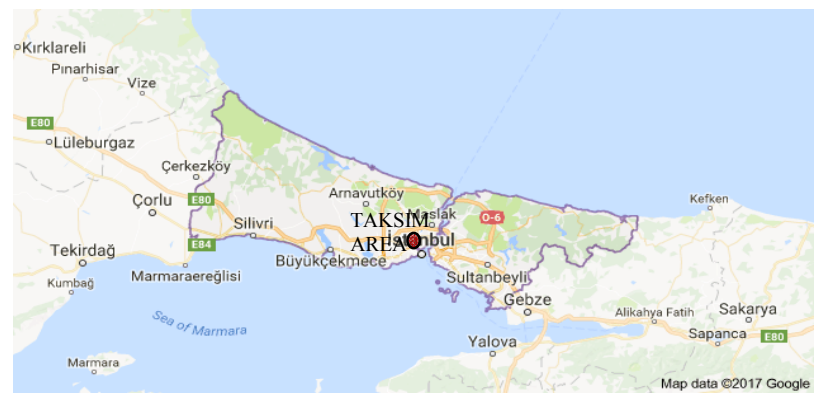

Figure 3: Map of Istanbul (google maps)

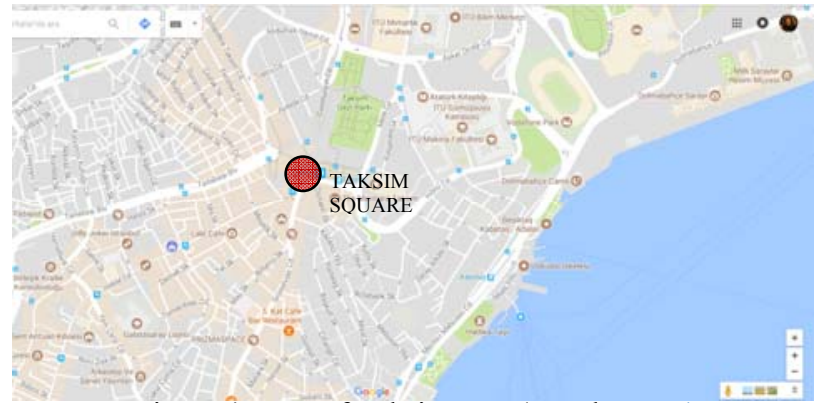

Figure 4: Map of Taksim area (google maps)
Taksim Square, designed in 1940s by French urban planner Henri Prost, is one of the places of significance not only throughout the history of the Republic of Turkey but also the Ottoman Empire with its tangible and intangible values, as a component of "collective memory". Since the beginning of the country's history, the area is linked to the modern face of Turkey as symbol of modernization process. In addition, it has been an area which attracted particular attention of governors for their political actions to reflect their social and cultural aspects (E. Güney and Vatan, 2017).

Taksim Square has witnessed to many important events of social significance (mainly, September 6-7, 1955 riots, Labour Day celebrations - May $1^{\text {st }}$, commemoration meetings of mothers of missing children and the recent Gezi protests). It could be stated that it has made it through many thresholds of "collective memory". Each threshold brought its own characteristics and has made changes in the area in terms of its atmosphere, visitors, main functions, social profile and day and night use. All these values of Taksim Square are intangible values of the site.

Besides the events, physical attributions of the area (tangible assets) also have important role in its statement as a place of "collective memory".Within the scope of this study, Istiklal Street, Ataturk Cultural Centre and the Republic monument are dealt with as tangible components of Taksim Square.

One of the significant attributes within Taksim Square area is the $2 \mathrm{~km}$ long Istiklal Street or "Istiklal" as referred to by Istanbul locals. "Istiklal" is a pedestrian mall connecting Tünel Square to the Taksim Square. Literal meaning of the street, Independence Street, is based on the history of the area as a face of modern Turkey. Both sides of the street are surrounded by shops, cafes, restaurants, exhibition halls, cinemas, bars and pubs, bookstores, flea markets and the like. All these places define the identity of the area as its particularities. Beside these tangible assets, the street is one of the main routes of protests, parades, celebrations, New Year celebrations, May $1^{\text {st }}$ labour day celebrations etc, which could be stated as its intangible values.

Particularly, in the past two decades this location had a 24-hour pedestrian traffic as a living place. Entertaining and socializing are the main characteristics and drivers of its lively hood. Mostly, young people and tourists are interested in the use of this area.

By the 2000s, political changes, increased migration to Istanbul, changing tourist profile, urban planning activities, attempts to establishing a new identity for the younger generation, created significant impacts on Taksim Square Neighbourhood. The area started to transform to conform to its new socio - spatial characteristics. Being the face of modern Turkey has been changed totally in opposite way. A new "collective memory" was created, alluding to the norms of the Ottoman era, which goes against a secular way of living. In order to succeed this aim, the characteristic, architectural identity of the area -especially Istiklal Street- was reestablished. Many places of entertainment were shut down. Night life in the area was minimised.

Thus, not surprisingly in May 2013, The "Gezi" Protests started as a simple protest demonstration against removal of the trees in Gezi Park area and had expanded as a conflict of intellectual people against government. It was followed by many supporting 
protests throughout country. Numbers of protesters increased to a significant number in a very short time.

Another tangible symbol of Taksim Square is the Atatürk Cultural Centre. Originally designed to be an opera house in 1946, the building had its grand opening as a multipurpose cultural centre in 1969. Following the opening, it was damaged severely due to a fire. In 1978, significant repairs it was officially open and was given the name "Atatürk Cultural Centre" (Uluşahin, online). This building was built to symbolize the modern face of Turkey and became as one of the icons of secular life in Istanbul city. The entrance of the building was designed to have a relationship with the square as an urban space and meeting point for its users. During Gezi Protests Atatürk Cultural Centre was one of the significant symbols for the protesters. Many posters were hung on its façade, mostly due to the governmental decisions which were first to close and then to demolish the building (Figure 5). So, the attempts to dismiss Gezi Park in order to reconstruct the old barracks and to demolish cultural centre had started as simple protest attempt which had changed to an armed conflict event. At the end, loss of life was one of the memories took place from that time.

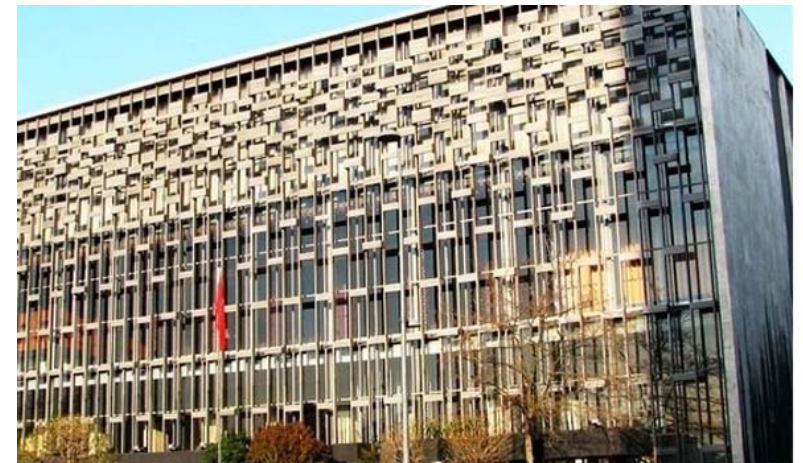

(a)

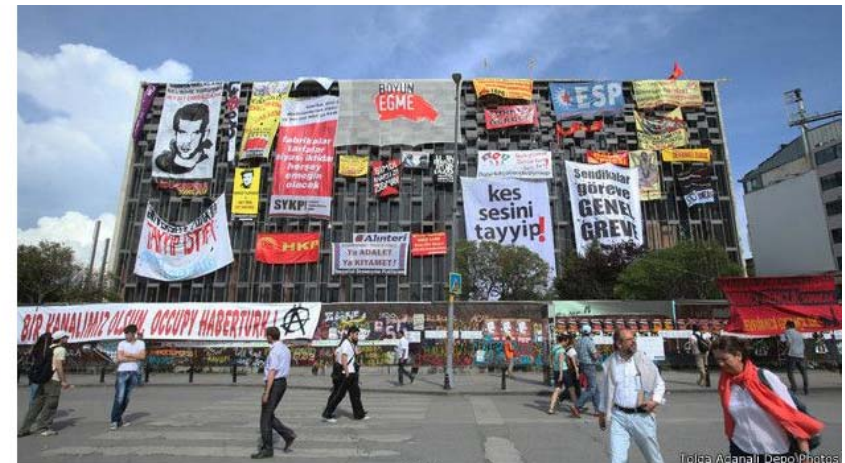

(b)

Figure 5: Atatürk Cultural Centre (a): before protests (Karakoç, www.arkitera.com/haber); (b): 2013 (https://istanbultourstudio.com)

The republic monument in Taksim Square also has a significant importance in Turkish history. After the establishment of the Republic of Turkey, Ankara was assigned as the capital of the new republic. However, the Taksim area was already a symbol of a western-lifestyle since the late Ottoman period (Figure 6). Accordingly, the Republic monument was built in 1928 by taking into consideration its environment as an urban public place (Ekenyazıcı \& Vatan, 2017).

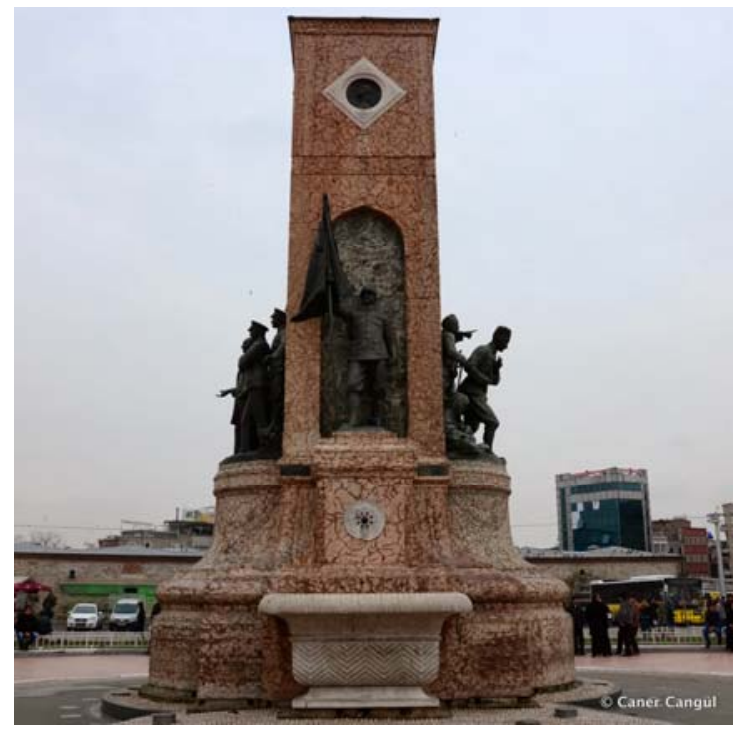

Figure 6: The republic monument in Taksim Square (Cangül, www.istanbulium.net)
Within the scope of this study Taksim Square and its surrounding area was inspected in order to document its intangible values and to trace the effects of the changes on its "collective memory". Although the main aim is to collect data regarding its intangible values, tangible components are taken into consideration as well, as an integral part of the intangible. Constitution of "collective memory" could be made and could be remembered within its whole concept formed by both tangible and intangible. Figure 10 shows a brief summary of collected data from Taksim Square area.

As a result of these changes, dramatic transformation of cultural identity and "collective memory" happened, spreading the seeds for new memories. The flow of young population and diverse profile is not visible anymore. Construction of new malls and a trial of designing new, modern facades of the existing buildings disrupted the perception of traditional and historic face of the area. In its current situation it is not easy to trace late Ottoman period and early modern republic character of the area.

\subsection{Kensington Market, Toronto, Ontario}

Kensington Market in Toronto, Ontario, Canada is a 27-hectare neighbourhood on the west side of downtown Toronto. It is bordered by Spadina Avenue on the west, Bathurst Street on the east, College Street on the north and Dundas Street West on the south. Within its boundaries it is a vibrant commercial and residential neighbourhood with distinctive narrow streets featuring small specialty stores. Behind and beside these storefronts are back alleyways leaning to rows of small late- $19^{\text {th }}$ century cottages. 


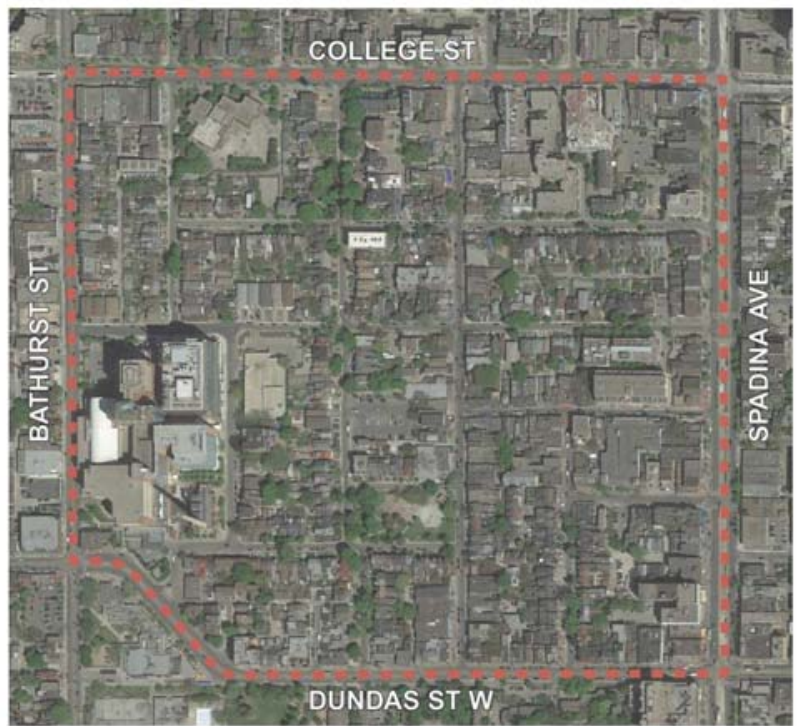

Figure 7: Kensington Market Location (Google Images)

The area was first developed in 1815 by George Taylor Denison, who subdivided the land and sold it to British and Irish immigrants in the $1850 \mathrm{~s}$ and $60 \mathrm{~s}$. As the area got populated, narrower cottages were built along the laneways that exist to day. In the early $20^{\text {th }}$ century, Kensington Market became a popular neighbourhood amongst Jewish immigrants from eastern and south-central Europe. The post-war period brought more immigrants from Eastern Europe, Portugal and Italy. In the 1960s, groups from the Carribeans, China and India were added to an increasingly diverse cultural mosaic of the neighbourhood. Over the years, Kensington Market's diverse history has created a continually evolving cultural and architectural environment that still is evident in the tangible fabric today.

In 2006, Kensington Market was designated as a National Historic Site due to its key elements demonstrating an eclectic variety of architectural styles and types as well as an authentic urban form in the North American context. Furthermore, the designation protects and celebrates the neighbourhoods dynamic balance between continuity and change in the pattern of usage; constantly influx due to changing demographics and

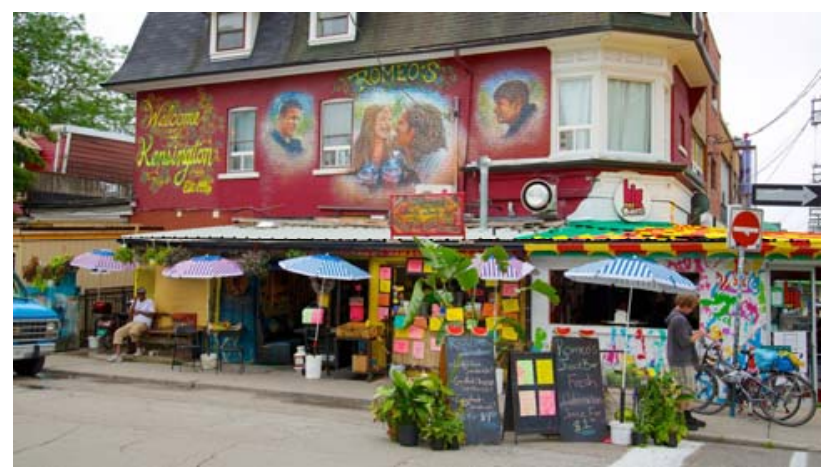

economic activities (Canada's Historic Places,2005).

Figure 8: A Typical Street View at the Kensington Market

Although diversity and adaptability are a part of the characteristics of the Kensington Market, the constant rapid change and economic turmoil that is presented in the most recent years have put the heritage neighbourhood at risk. New developments in the area are erasing the patina of the past as well as the architectural typologies of the neighbourhood that are reminiscent of the demographic groups that have occupied the neighbourhood in the past.
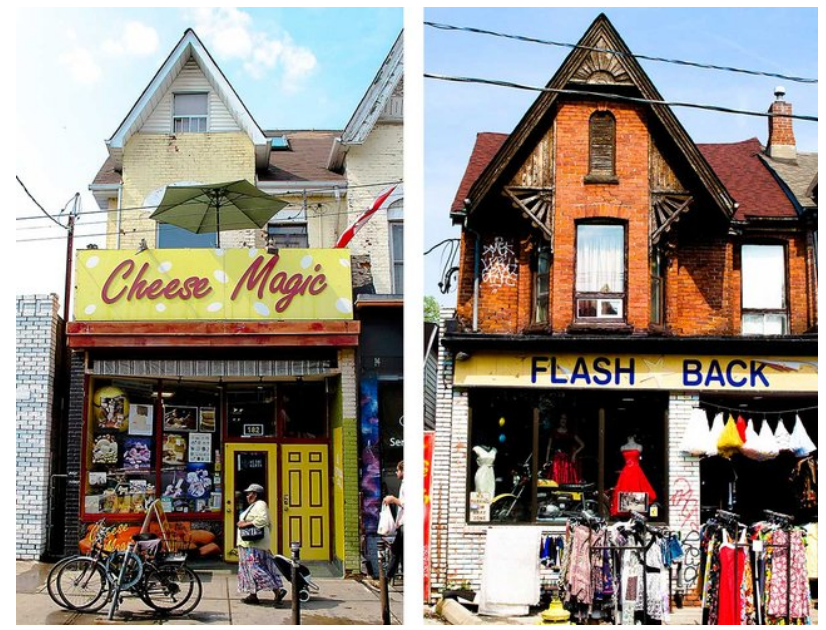

Figure 9: Existing Street facades of the Kensington Market (www.NowToronto.com)

\section{RESULTS}

\subsection{Findings through case studies}

Although selected two case studies are located in very different geographies and include very different characteristics there are similarities in terms of change and transformation of "collective memory" due to the events and changes of the communities forming these places.

Figure 10 shows the collected data of Taksim Square area. By tracing the form it is possible to see that main threats to intangible values of the site are based on the changing profile of its users. The new visitor profile has brought new demands to the area. Increasing number of Eastern tourists resulted in the need for more shopping malls, mosques, traditional food stores, and souvenir shops. Such demands changed the dominant user profile of the area from secular students and younger generation to groups of Middle Eastern tourists and their families.

All these changes are results of political manipulations. Due to the power of politics it was easy to make dramatic change in the area, even to send away the young population. It is no longer allowed to make protests or Labour Day celebrations - May $1^{\text {st }}$ in Taksim Square which were among the main values and memories of the site. 


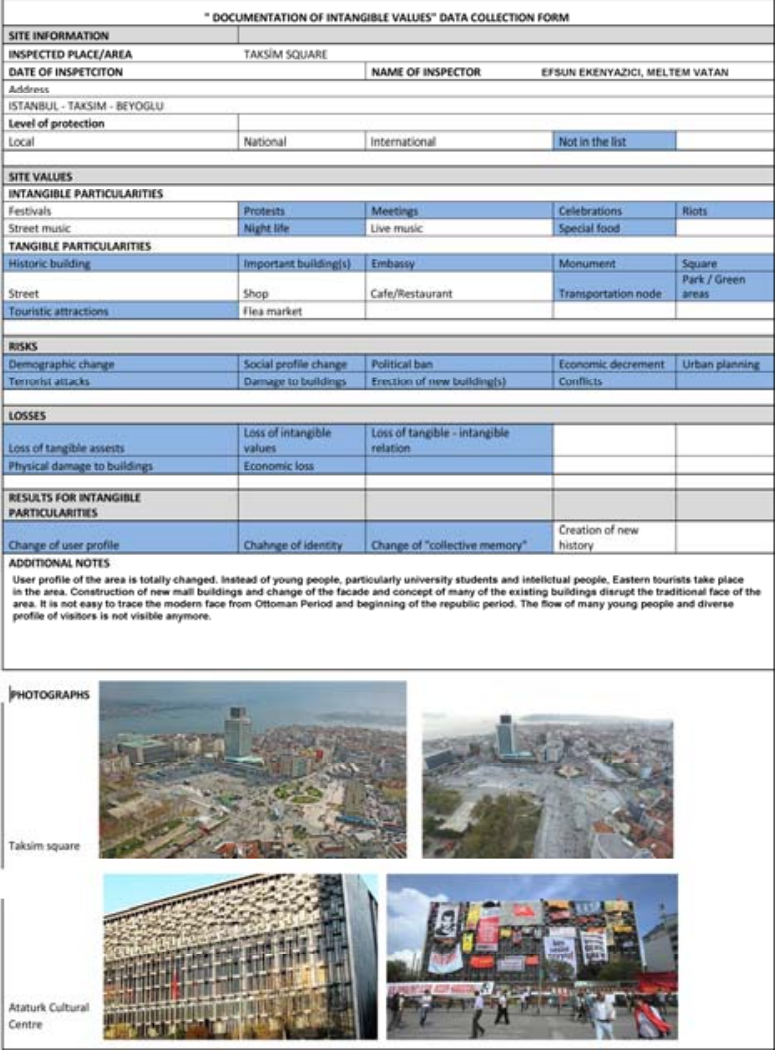

Figure 10: Collected data of Taksim Square

When when we look at the changes that have happened in Kensington Market over the recent years, even though the changes are not as drastic as it is in the case of Taksim Square, it does create a risk in terms of the preservation of the heritage fabric. The slower change that is happening due to changing demographics and user profiles are altering the streetscapes. As mentioned before, as the new demographic groups enter and "occupy" the neighbourhood, the patina of the previous user groups are being erased. The changing tangible environment results or will eventually result in the erasure or alteration of "collective memory".

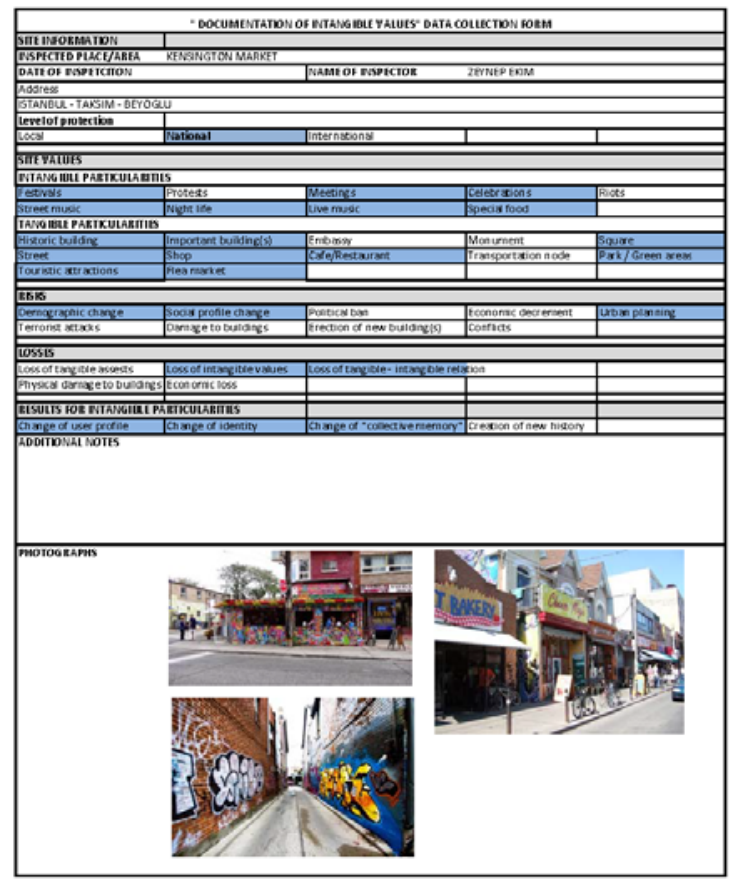

Figure 11: Collected data of Kensington Market

\subsection{Conclusion}

Two case studies that were investigated show that intangible values of the places are the drivers of "collective memory". They are very important to generate the perception of communities or users of the areas. For being able to memorize any place, event, tradition etc. the human brain needs to picture scene in its entirety with its all figures and figurants. Thus, to create a memory, in addition to the intangible it is indispensable to memorize the tangible within its concept and space, with its tangible components as well.

Based on the findings of the conducted case studies in this paper it is possible to state that when the aim is to mitigate the risks of "collective memory" the intangible values need to be connected to the tangible components. So, documentation is the main tool for risk mitigation. The attempt of intangible documentation is done within the scope of this study. The main components of the data collection form are based on the events and traditions as intangible part and particularly the photographs are the tangible part to be able to picturize the memory and to trace the changes and transformation.

Amalgamated results of the two cases in terms of risk mitigation are listed below:

- Definition and specification of characteristics of the place

- Definition of the threats in terms of preservation heritage and "collective memory"

- Distinguishing controllable part within heritage preservation and uncontrollable part due to politics

- Starting with the planning process of controllable part

- Documentation of the site

- Making connection between intangible and tangible while documenting the site

- Taking pictures of particular events having tradition to be done in the site in order to document the intangible

- Documentation of the user profile and community

- Trace the changes and transformation of users and community of the place

- Preservation of heritage components as intangible assets of the place

- Consideration of the heritage values in urban planning

- Determination of community and users' profile characteristics and requirements

- To not consider relocation of the exciting community as a first decision

- To preserve longevity of the place to keep the existing use of the place.

It is very important to highlight that when the issue is "collective memory" the topic includes wide range of characteristics. It is not possible to manage and mitigate all the risks within the concept of heritage risk mitigation or management. So, one of the important challenges is to prepare short term and long term plans and scenarios to be able to manage the risks other than heritage issues. 


\section{REFERENCES}

AKM: Türkiye'nin ilk opera binası çürümeye mi terk edildi? URL:http://www.bbc.com/turkce/haberler/2015/03/150326_ak m_ilk_opera_binasi [cited 08.04.2017]

Canada's Historic Places, "Kensington Market National Historic Site of Canada", 2005, http://www.historicplaces.ca/en/rep-reg/place-

lieu.aspx?id=14463.

Rose-Redwood, R., Alderman, D., Azaryahu, M., 2008, "Collective memory and the politics of urban space: an introduction", Geo Journal 73:161-164.

Foote, K. E., and Azaryahu, M., 2007, Toward a Geography of Memory: Geographical Dimensions of Public Memory and Commemoration, Journal of Political and Military Sociology, 35/1: $125-144$.

Hoelscher, S. and Alderman, D., 2004, Memory and Place: Geographies of a Critical Relationship, Social and Cultural Geography 5: $347-355$.

Cangül, C. URL: http://www.istanbulium.net/2014/01/taksimcumhuriyet-anitinin-yuzeylerinde-ne-var.html [cited 27.06.2017]

Karakoç, N. Atatürk Kültür Merkezi Onarılmalı mı, Yıkılmalı mi? URL: http://www.arkitera.com/haber/26855/ataturk-kulturmerkezi-onarilmali-mi-yikilmali-mi_[cited 22.12.2016]

Taylor Hazell Architects, Urban Strategies, Archeological Services Inc, The City of Toronto, "Kensington Market Heritage Conservation District Study", 2017, https://hcdtoronto.files.wordpress.com/2017/02/kensington-hcdstudy_ccm2-final-presentation-reduced1.pdf.

Till, K., 2006, Memory Studies, History Workshop Journal 62: $325-341$.

Romao, X., Pauperio, E., Pereira, N., 2016, A Framework for the Simplified Risk Analysis of Cultural Heritage Assets, Journal of Cultural Heritage 20: 696 - 708 .

UNDP, Disaster Risk Assessment, 2010, www.undp.org

Ekenyazici, G. E., Vatan, M., "Heritage protection vs time flow: Case study of Istanbul Taksim area as a "place of memory", 12th ICOMOS International Committee on Theory and Philosophy of Conservation and Restoration Scientific Conference - Place of Memory - Protection, Conservation, Interpretation - 9th edition in Florence, 8 - 10 Mart 2017

Trigg, D., 2013, The Memory of Place: A Phenomenology of the Uncanny. Ohio University Press.

Leite, J.M.V., 2009, "Cultural Heritage and Monument, a Place in Memory", City \& Time 4 (2): 3. URL:

http://www.ct.cecibr.org [cited 22.6.2017]

Uluşahin, A. Atatürk Kültür Merkezi'nin 70 yıllık tarihi, URL: http://kulturservisi.com/p/ataturk-kultur-merkezinin-70-yilliktarihi [cited 22.12.2016] 